\title{
Hidrolisis Pati Ganyong (Canna edulis) dengan Amilase Bakteri Flavobacterium sp. PTBT I untuk Produksi Bioetanol
}

\author{
Dian Riana Ningsih"), Zusfahair, dan Amin Fatoni \\ Program Studi Kimia, Jurusan Matematika dan Ilmu Pengetahuan Alam, FST \\ Universitas Jenderal Soedirman, Purwokerto 53123 \\ Diterima 25-05-2010 Disetujui 09-05-2012
}

\begin{abstract}
Bioethanol is an alternative energy of fuels produced from vegetable materials. Vegetable materials that can be used as raw material for bioethanol is ganyong because it contains $22.60 \mathrm{~g}$ starch in $100 \mathrm{~g}$ ganyong. The production of bioethanol from starch material consisted of two steps, hydrolysis and fermentation. One of the steps to increase the value of bioethanol from starch of ganyong was hydrolysis process using thermostable amylase enzyme isolated from Flavoacterium sp. PTBT I bacteria was isolated from hot spring of Pancuran Tujuh Baturraden. The aim of this research was to use thermostable amylase to hydrolyze starch of ganyong and glucose produced to result bioethanol. The result of this research showed that the optimum condition hydrolysis starch of ganyong was using thermostable amylase acquired at substrate concentration of $3 \%(\mathrm{~b} / \mathrm{v})$, and incubation time of about 75 minutes. The value of bioethanol increased with time of fermentation, from the first to fourth day, which was $0.8361 ; 2.2379 ; 5.7590$ and $10.5787 \%(\mathrm{v} / \mathrm{v})$, respectively.
\end{abstract}

Keywords: amylase, bioethanol, hydrolysis, starch of ganyong

\begin{abstract}
ABSTRAK
Bioetanol adalah salah satu alternatif pengganti Bahan Bakar Minyak (BBM) yang berasal dari bahan nabati. Bahan nabati yang dapat digunakan sebagai bahan baku bioetanol adalah ubi ganyong karena mengandung pati 22,60 g dalam $100 \mathrm{~g}$ ubi ganyong. Pembuatan bioetanol dari bahan berpati dilakukan sebanyak dua tahap, yaitu hidrolisis dan fermentasi. Salah satu upaya peningkatan kadar bioetanol dari pati ganyong adalah proses hidrolisis menggunakan enzim amilase termostabil yang diisolasi dari bakteri Flavobacterium sp. PTBT I berasal dari sumber air panas Pancuran Tujuh Baturraden. Tujuan penelitian ini adalah penggunaan amilase termostabil untuk hidrolisis pati ganyong dan glukosa yang dihasilkan digunakan untuk produksi bioetanol. Hasil penelitian menunjukkan bahwa kondisi optimum hidrolisis pati ganyong yang menggunakan amilase termostabil ini diperoleh pada saat konsentrasi substrat 3\% (b/v) dan waktu inkubasi 75 menit. Kadar bioetanol yang diperoleh meningkat dengan semakin lama waktu fermentasi yaitu hari ke-1 sampai hari ke-4, masing-masing bioetanol yang dihasilkan sebesar 0,8361; 2,2379; 5,7590 dan 10,5787\% (v/v).
\end{abstract}

Kata Kunci: amilase, bioetanol, hidrolisis, pati ganyong

\section{PENDAHULUAN}

Saat ini kebutuhan Bahan Bakar Minyak (BBM) di Indonesia mencapai $52 \%$ dari total kebutuhan energi nasional. Sebagian besar BBM tersebut bersubsidi, bahkan

*Telp: +628164285251

Email: deeyan_bik@yahoo.com pada tahun 2006 besar subsidi mencapai Rp60,6 triliun dan sekitar $43 \%$ kebutuhan BBM dalam negeri masih diimpor. Cadangan minyak bumi Indonesia saat ini juga tinggal 0,5\% dari cadangan minyak dunia dan diperkirakan 18 tahun mendatang minyak bumi akan habis (Prihandana et al. 2007). Kenyataan ini dapat mengakibatkan kelangkaan 
BBM yang merupakan sumber daya alam tidak terbaharui, sehingga tidak ada pilihan lain kecuali mencari energi alternatif yaitu energi biomassa.

Salah satu energi biomassa adalah bietanol sebagai alternatif pengganti BBM (Anindyawati 2009). Bioetanol disarankan dalam upaya penghematan BBM karena berasal dari sumber daya alam terbaharui. Bioetanol merupakan etanol hasil proses fermentasi biomassa dengan bantuan mikroorganisme. Biomassa sebagai bahan baku bioetanol adalah polisakarida yang melimpah di alam, baik selulosa maupun pati (Yoswathana et al. 2010; Roslan et al. 2011 ). Biomassa yang dapat dijadikan bioetanol salah satunya adalah ubi ganyong, karena kandungan patinya tinggi, sebesar 22,60 g dalam $100 \mathrm{~g}$ ubi ganyong (Lingga 1986).

Proses pembuatan bioetanol dari bahan berpati dilakukan dalam dua tahap, yaitu hidrolisis dan fermentasi (Merina \& Trihadiningrum 2011; Yoshimura et al. 2012). Menurut Agu et al. (1997), pengubahan pati menjadi glukosa adalah proses hidrolisis, selanjutnya proses fermentasi, yaitu pengubahan glukosa menjadi etanol dengan bantuan ragi. Proses hidrolisis pada prinsipnya adalah pemutusan rantai polimer pati menjadi unit-unit glukosa. Hal ini dapat dilakukan dengan cara enzimatis maupun kimiawi. Penelitian pembuatan bioetanol dari pati ganyong menggunakan metode kimiawi telah dilakukan oleh Putri dan Sukandar (2008), yaitu hidrolisis asam dengan rendemen bioetanol sebesar 4,84\%. Penggunaan asam sebagai katalis dalam proses hidrolisis jarang digunakan karena menghasilkan glukosa yang sedikit akibat pemutusan rantai polimer pati terjadi secara acak. Penggunaan asam tersebut juga menimbulkan korosi yang dapat mencemari lingkungan (Samsuri et al. 2007).

Salah satu upaya peningkatan kadar bioetanol dari pati ganyong adalah proses hidrolisis menggunakan enzim amilase termostabil dari bakteri Flavobacterium sp. PTBT I. Penggunaan enzim termostabil ini diharapkan meningkatkan laju reaksi hidrolisis sehingga dihasilkan glukosa lebih banyak dan pada akhirnya diperoleh bioetanol dengan kadar tinggi. Keuntungan lain yang diperoleh menggunakan enzim yang aktif pada suhu tinggi diantaranya menurunkan resiko kontaminasi, meningkatkan kecepatan reaksi sehingga menghemat waktu, tenaga, dan biaya, serta menurunkan viskositas larutan fermentasi sehingga memudahkan proses produksi (Rahayu 2004). Penelitian ini mempunyai tujuan mengetahui penggunaan amilase termostabil yang diisolasi dari bakteri Flavobacterium sp. PTBT I untuk hidrolisis pati ganyong dan glukosa yang dihasilkan digunakan untuk produksi bioetanol.

\section{BAHAN DAN METODE}

Alat-alat yang digunakan adalah tabung reaksi, erlenmeyer, beaker glass, pipet tetes, mikropipet soccorex, tabung mikro, tabung sentrifuge, autoklaf, shakerbath, inkubator venticel, kompor listrik, penangas air, magnetic stirer, sentrifuge $\mathrm{T} 120$, neraca analitik, $\mathrm{pH}$ meter Hanna Instrument, jarum ose, spektrofotometer UV-Visible Spectronic Genesys 20, Kromatografi Gas-Cair. Bahan yang digunakan: umbi ganyong, ekstrak kasar enzim amilase yang diisolasi dari bakteri Flavobacterium PTBT I, propanol, ragi, dan alkohol $70 \%$.

Penyiapan Pati Ganyong. Kulit umbi ganyong dikupas menggunakan pisau dan dicuci bersih. Umbi ganyong tersebut kemudian diparut. Hasil dari parutan umbi ganyong selanjutnya dibungkus dengan kain basah dan diperas (disaring), Filtrat umbi ganyong ditampung dalam wadah dan dibiarkan beberapa jam hingga terbentuk endapan. Endapan dipisahkan dari cairan kemudian endapan dioven pada suhu $50^{\circ} \mathrm{C}$ (atau dijemur hingga kering di bawah sinar matahari selama 3-5 hari). Endapan yang telah kering merupakan pati umbi ganyong yang digunakan sebagai substrat dalam penentuan kondisi optimum dalam hidrolisis pati menjadi glukosa.

Penentuan Konsentrasi Substrat Optimum. Prosedur kerja penentuan substrat optimum sama seperti uji aktivitas enzim amilase (Metode Nelson-Somogyi dalam Alexander \& Joan 1993). Variasi konsentrasi substrat yang digunakan adalah $1,2,3,4,5$, dan $6 \%$ (b/v).

Penentuan Waktu Inkubasi Optimum. Prosedur kerja penentuan waktu inkubasi optimum sama seperti uji aktivitas enzim amilase (Metode Nelson-Somogyi dalam Alexander \& Joan 1993) pada konsentrasi substrat optimum. Variasi waktu inkubasi yang digunakan adalah 30-105 menit dengan interval 15 menit.

Uji Aktivitas Amilase Mengunakan Metode NelsonSomogyi (Alexander \& Joan 1993). Sebanyak 0,1 g serbuk pati dilarutkan dalam $10 \mathrm{~mL}$ bufer fosfat $\mathrm{pH} 8$ masing-masing 
duplo. Larutan ini disebut larutan pati $1 \%$. Larutan diinkubasi dalam oven dengan suhu $70^{\circ} \mathrm{C}$ selama 15 menit. Gelatinisasi selesai dilanjutkan dengan uji aktivitas.

Tabung kontrol diisi dengan 0,5 mL larutan enzim dan $0,5 \mathrm{~mL} \mathrm{NaCl} 0,85 \%$. Ke dalam tabung sampel dimasukkan $5 \mathrm{~mL}$ substrat pati $1 \%$, pada tabung kontrol ditambahkan $1 \mathrm{~mL}$ larutan Na-Wolframat $10 \%$ dan $1 \mathrm{~mL}$ asam sulfat $2 / 3$ N. Kedua tabung selanjutnya diinkubasi pada suhu sesuai habitat asalnya selama 5 menit. Ke dalam tabung reaksi sampel ditambahkan $0,5 \mathrm{~mL}$ larutan enzim dan $0,5 \mathrm{~mL} \mathrm{NaCl}$ 0,85\%, kemudian inkubasi dilanjutkan selama 30 menit. Aktivitas enzim dihentikan dengan menambahkan ke dalam tabung sampel $1 \mathrm{~mL}$ larutan Na-Wolframat $10 \%$ dan $1 \mathrm{~mL}$ asam sulfat $2 / 3$ N. Ke dalam tabung kontrol ditambahkan $5 \mathrm{~mL}$ substrat pati $1 \%$.

Aktivitas amilase ditentukan dengan cara mengukur terbentuknya gula pereduksi menurut metode NelsonSomogyi, yaitu ke dalam tabung dimasukkan masingmasing 0,2 mL larutan sampel, 0,2 mL larutan kontrol, dan 0,2 mL larutan glukosa standar 100, 200, 300, 400, $500 \mu \mathrm{g} / \mathrm{mL}$. Masing-masing larutan ditambahkan $0,2 \mathrm{~mL}$ reagen $\mathrm{Cu}$-tartrat alkalis, kemudian diaduk. Tabung reaksi ditutup dan dipanaskan dalam penangas air mendidih selama 30 menit, kemudian didinginkan dalam air dan ditambahkan 0,2 $\mathrm{mL}$ reagen arsenomolibdat. Campuran dihomogenkan lalu diencerkan dengan menambahkan 7,4 $\mathrm{mL}$ akuades. Serapan diukur pada panjang gelombang $660 \mathrm{~nm}$, kemudian dihitung dengan rumus berikut:

$$
\text { aktivitas enzim }=\frac{(2)-(1)}{0,18} \times \text { faktor pengenceran }
$$

Banyaknya gula pereduksi yang dibebaskan $/ \mathrm{mL}=(2)-(1)$ Keterangan: $(1)=$ konsentrasi glukosa kontrol $(\mu \mathrm{g} / \mathrm{mL})$

$$
\text { (2) = konsentrasi glukosa sampel }(\mu \mathrm{g} / \mathrm{mL})
$$

Faktor pengenceran $=$ volume total $/($ volume enzim $\mathrm{x}$ filtrat sampel)

Satu unit aktivitas amilase didefinisikan sebanyak $0,18 \mathrm{mg}$ gula pereduksi $(1 \mu \mathrm{mol})$ yang dibebaskan per $\mathrm{mL}$ enzim pada kondisi percobaan.

Fermentasi Glukosa Menjadi Bioetanol. Kondisi optimum hidrolisis pati telah diperoleh maka percobaan selanjutnya adalah hidrolisis pati ganyong pada kondisi optimum tersebut hingga dihasilkan glukosa dengan kadar optimum. Glukosa yang dihasilkan kemudian difermentasi menggunakan ragi sehingga dihasilkan bioetanol. Suspensi ragi konsentrasi $6 \%$ (b/v) dibuat dengan cara mencampurkan serbuk ragi sebanyak $33 \mathrm{mg}$ dengan bufer pH 6,5. Larutan pati sebanyak $100 \mathrm{ml}$ diinkubasi dalam oven dengan suhu $70^{\circ} \mathrm{C}$ selama 15 menit, lalu dipindahkan ke shakerbath pada suhu optimum, ditambah $10 \mathrm{~mL}$ ekstrak kasar amilase yang diperoleh dari percobaan sebelumnya dan diinkubasi pada waktu inkubasi optimum. Setelah didapat larutan glukosa, selanjutnya ditambahkan larutan ragi kemudian diinkubasi pada keadaan tertutup selama 1; 2; 3 dan 4 hari pada suhu $37^{\circ} \mathrm{C}$. Percobaan ini dirancang dalam bagan rancangan percobaan dengan variabel bebas lama fermentasi dan variabel tetap dosis ragi $6 \%$ (b/v) yang masing-masing perlakuan diulang 3 kali. Bioetanol yang diperoleh dari proses fermentasi kemudian didestilasi, dan ditentukan kadarnya dengan kromatografi gas-cair menggunakan standar dalam propanol.

\section{HASIL DAN PEMBAHASAN}

Penentuan Konsentrasi Substrat dan Lama Inkubasi Optimum Hidrolisis Pati Ganyong Menjadi Glukosa. Nilai $\mathrm{pH}$ dan suhu optimum enzim amilase yaitu pada $\mathrm{pH} 8$ dan $75^{\circ} \mathrm{C}$ (data penelitian sebelumnya) selanjutnya digunakan untuk penentuan konsentrasi substrat dan lama inkubasi pada optimasi hidrolisis menghasilkan glukosa yang diaplikasikan untuk pembuatan bioetanol.

Penentuan Konsentrasi Substrat Optimum. Penentuan konsentrasi substrat dengan variasi konsentrasi bertujuan untuk mendapatkan suatu konsentrasi yang menghasilkan glukosa secara optimum. Konsentrasi substrat optimum yang dihasilkan pada saat aktivitas enzim amilase optimum ditunjukkan pada Gambar 1.

Aktivitas enzim amilase bertambah dengan meningkatnya konsentrasi substrat sampai pada konsentrasi 3\% dengan nilai aktivitas enzim amilase sebesar 22,5964 U/mL, dan diperoleh konsentrasi glukosa sebesar $50,8419 \mu \mathrm{g} / \mathrm{mL}$, selanjutnya penambahan konsentrasi substrat menyebabkan penurunan aktivitas enzim amilase. Kecepatan reaksi enzimatik dipengaruhi oleh konsentrasi substrat, yaitu pada konsentrasi substrat rendah, bagian aktif enzim hanya menampung sedikit substrat. Konsentrasi substrat bila diperbesar, semakin banyak substrat yang dapat berhubungan dengan enzim pada bagian aktif 


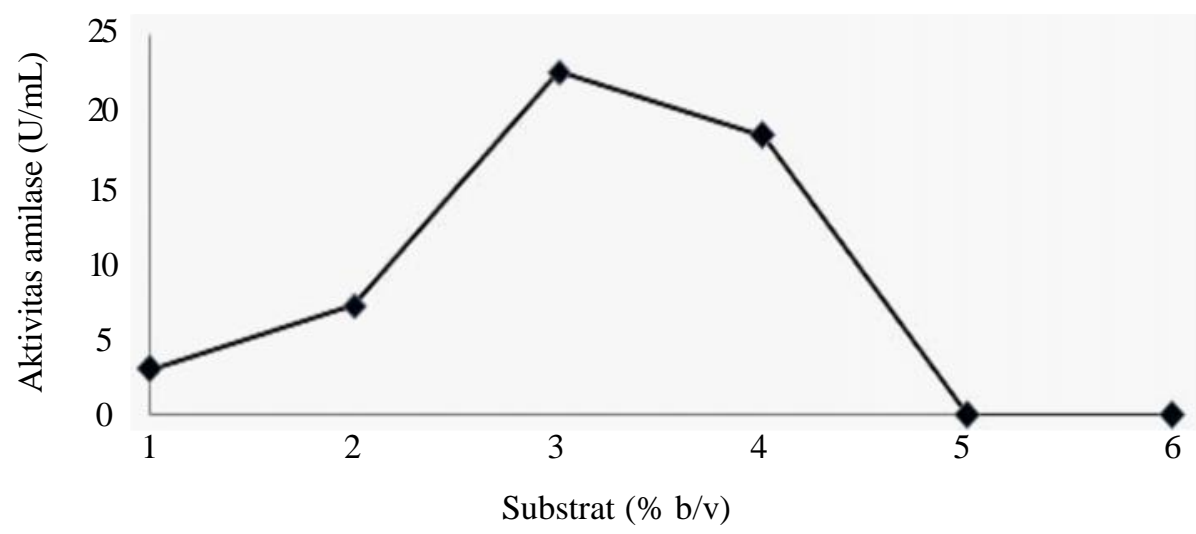

Gambar 1 Pengaruh variasi konsentrasi substrat pati ganyong terhadap aktivitas amilase isolat Flavobacterium sp. PTBT I

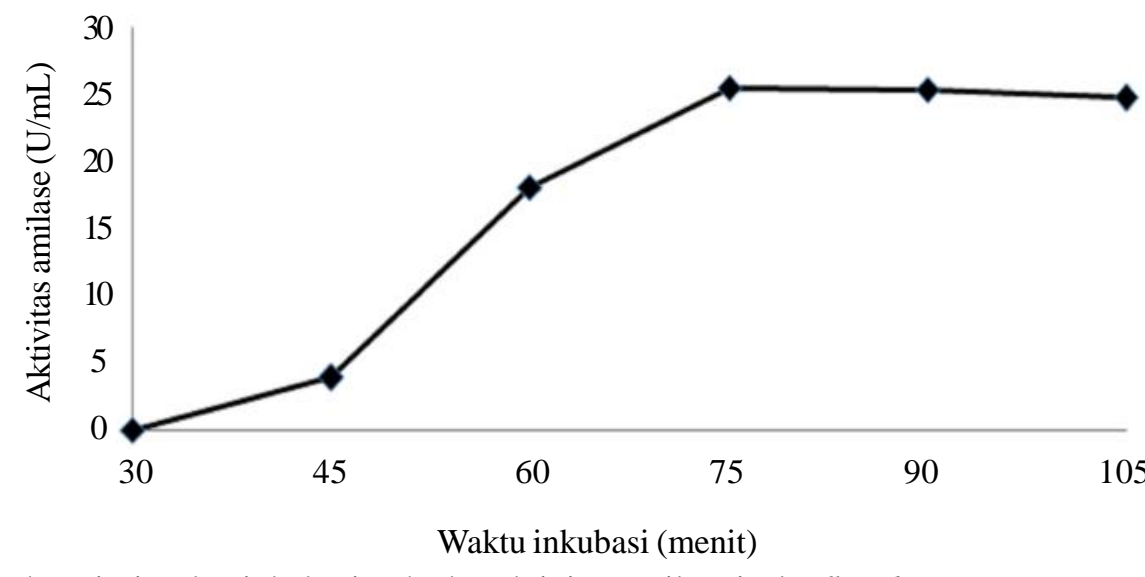

Gambar 2 Pengaruh variasi waktu inkubasi terhadap aktivitas amilase isolat flavobacterium sp. PTBT I

tersebut, dengan demikian konsentrasi kompleks enzim substrat semakin besar dan hal ini menyebabkan semakin besarnya kecepatan reaksi enzimatik. Pada suatu batas konsentrasi substrat tertentu, semua bagian aktif enzim telah dipenuhi oleh substrat atau enzim telah jenuh dengan substrat. Bertambahnya konsentrasi substrat dalam keadaan ini tidak menyebabkan bertambahnya konsentrasi kompleks enzim substrat, sehingga produk reaksi tidak bertambah besar (Poedjadi 1994). Penurunan aktivitas amilase di atas konsentrasi substrat 3\%, terjadi karena inhibisi oleh substrat terhadap enzim amilase, sehingga produk reaksi menjadi lebih sedikit. Menurut Judoamidjojo et al. (1992), substrat dapat menginhibisi molekul enzim sehingga laju reaksinya menurun pada konsentrasi substrat yang tinggi meskipun kinetika Michaelis-Menten ditaati pada konsentrasi substrat yang rendah.
Penentuan Lama Inkubasi Optimum. Penentuan lama inkubasi optimum bertujuan untuk mengetahui pada waktu inkubasi berapa enzim amilase mempunyai aktivitas optimum. Pada saat enzim amilase mempunyai aktivitas optimum, maka akan dihasilkan glukosa yang optimum juga. Aktivitas enzim amilase pada berbagai waktu inkubasi dapat dilihat pada Gambar 2.

Waktu inkubasi optimum enzim amilase adalah 75 menit dengan nilai aktivitas unit sebesar 25,4651 U/mL. Konsentrasi glukosa pada saat aktivitas enzim amilase optimum diperoleh sebesar 57,2965 $\mu \mathrm{g} / \mathrm{mL}$. Aktivitas enzim amilase terus mengalami kenaikan dari waktu inkubasi 3075 menit. Hal ini disebabkan substrat pati ganyong dihidrolisis oleh enzim amilase menghasilkan glukosa yang semakin meningkat. Semakin lama waktu inkubasi maka kontak enzim dengan substrat semakin sering terjadi, 
sehingga peluang dihasilkannya produk juga semakin banyak. Setelah 75 menit, tidak terjadi penurunan maupun kenaikan yang signifikan dari aktivitas enzim amilase, tetapi cenderung stabil. Hal ini mengindikasikan bahwa pati ganyong sebagai substrat sebagian besar telah terhidrolisis menghasilkan glukosa yang lebih banyak dari campuran reaksi, selain itu aktivitas enzim amilase yang relatif stabil setelah waktu inkubasi 75 menit juga karena faktor keterbatasan enzim amilase dan substrat pati ganyong yang digunakan dalam reaksi hidrolisis.

Produksi Bioetanol dari Pati Ganyong dengan Lama Fermentasi Berbeda. Produksi bioetanol dari pati ganyong dalam penelitian ini dilakukan dalam tiga tahap yaitu hidrolisis, fermentasi dan destilasi. Tahap hidrolisis merupakan proses pemecahan polimer pati menjadi monomer yang lebih sederhana yaitu glukosa. Tahap ini dilakukan pada kondisi optimum hidrolisis pati ganyong, yaitu konsentrasi substrat optimum dan waktu inkubasi optimum. Konsentrasi substrat yang digunakan adalah $3 \%$ (b/v) dan diinkubasi dengan enzim amilase yang sudah dikarakterisasi selama waktu inkubasi optimum yaitu 75 menit. Hasil hidrolisis berupa glukosa dengan konsentrasi $57,2965 \mu \mathrm{g} / \mathrm{mL}$ diperoleh saat aktivitas enzim amilase optimum. Glukosa hasil hidrolisis selanjutnya difermentasi dengan ragi konsentrasi 6\%, kemudian diinkubasi pada suhu $37^{\circ} \mathrm{C}$ pada kondisi anaerob. Proses fermentasi dilakukan dengan variasi waktu yaitu 1; 2; 3 dan 4 hari untuk mengetahui pengaruh lama fermentasi terhadap kadar bioetanol yang dihasilkan. Bioetanol hasil fermentasi selanjutnya didestilasi untuk memisahkan bioetanol dengan zat-zat lain berdasarkan perbedaan titik didih. Pengaruh lama fermentasi terhadap kadar bioetanol dapat dilihat pada Gambar 3.

Berdasarkan Gambar 3 menunjukkan bahwa semakin lama fermentasi, kadar bioetanol yang diperoleh semakin meningkat, yaitu pada hari ke-1 sampai hari ke-4 fermentasi diperoleh kadar bioetanol sebesar 0,8361; 2,2379; 5,7590 dan $10,5787 \%$ (v/v). Kadar bioetanol yang semakin meningkat dengan bertambahnya lama fermentasi, dikarenakan kadar glukosa hasil hidrolisis pati ganyong sebagai sumber karbon mencukupi untuk pertumbuhan Saccharomyces cerevisiae (dalam ragi) menghasilkan etanol, selain itu juga karena faktor suhu $37^{\circ} \mathrm{C}$ dan $\mathrm{pH}$ 6,5 yang terjaga selama proses fermentasi, sehingga sel $S$. cerevisiae terus dapat tumbuh dan mengeluarkan enzim zimase yang memiliki fungsi utama merombak glukosa menjadi etanol (Wahyusi 2004). Faktor lain yang mendukung meningkatnya kadar bioetanol adalah ragi yang digunakan mengandung nutrisi tambahan (additive nutrition) yang menunjang viabilitas sel $S$. cerevisiae yang diawetkan dalam kemasan. Sumber karbohidrat dalam bentuk monosakarida (sukrosa, fruktosa dan glukosa) di dalam ragi berfungsi sebagai agen nutrisi untuk pertumbuhan dan sodium karbonat untuk kontrol $\mathrm{pH}$ serta vitamin B sebagai pembawa gugus asetaldehida (Reed \& Nagodawithana 1991). Bioetanol yang dihasilkan dari kulit pisang kepok diperoleh pada waktu fermentasi optimum hari ke-4 dengan kadar etanol sebesar 0,446\%

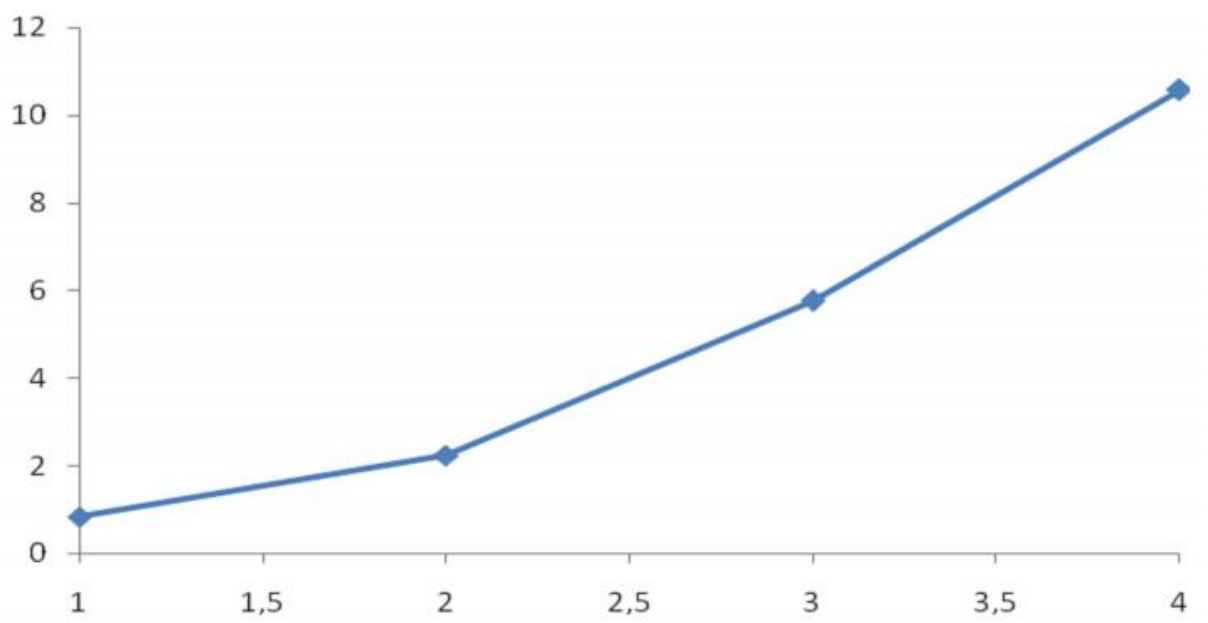

Gambar 3 Pengaruh lama fermentasi terhadap kadar bioetanol dari pati ganyong 

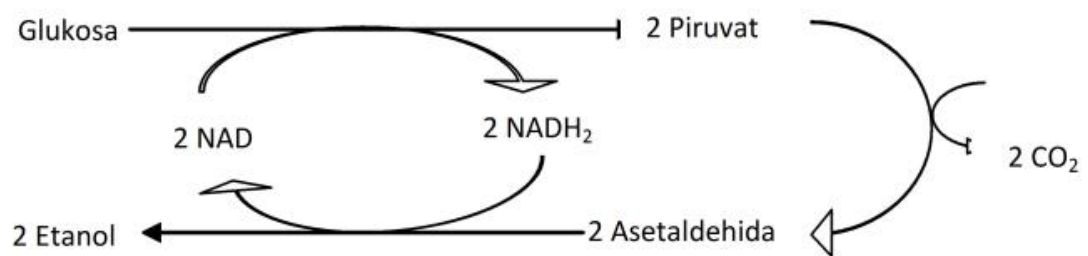

Gambar 4 Alur Pembentukan etanol dari glukosa (Schlegel 1994)

(Wulan et al. 2009). Pengaruh lama fermentasi terhadap kadar bioetanol dari pati jagung juga dilaporkan oleh Wahyusi (2004) bahwa semakin lama fermentasi yaitu hari ke-1 sampai hari ke-5 bioetanol yang dihasilkan semakin meningkat, dengan kadar etanol tertinggi pada hari ke-5 sebesar $9,06 \%$.

Proses pemecahan polimer pati (karbohidrat) menjadi glukosa yang selanjutnya diubah menjadi etanol merupakan proses yang berlangsung dalam beberapa tahap, yang masing-masing tahapnya dikatalisis oleh enzim. Proses ini bertujuan untuk mendapatkan energi yang tersimpan dalam senyawa produk reaksi yaitu etanol sebagai bahan bakar (Martoharsono 1977). Menurut Schlegel (1994), fermentasi glukosa menjadi etanol dan karbondioksida oleh $S$. cerevisiae terjadi melalui alur fruktosa difosfat. Transformasi piruvat menjadi etanol mencangkup dua tahap, pertama piruvat didekarboksilasi menjadi asetaldehida oleh piruvat dekarboksilase dengan keikutsertaan tiamin pirofosfat, selanjutnya pada tahap kedua asetaldehida direduksi oleh $\mathrm{NADH}_{2}$ menjadi etanol dan dikatalisis oleh alkohol dehidrogenase. Pada pemindahan $\mathrm{H}$ ini digunakan hidrogen yang terjadi pada dehidrogenasi triosafosfat, dengan demikian neraca reduksi oksidasi dapat diseimbangkan. Proses pengubahan glukosa menjadi etanol dapat dilihat pada Gambar 4.

\section{SIMPULAN}

Berdasarkan hasil penelitian dapat disimpulkan: kondisi optimum untuk hidrolisis pati ganyong menjadi glukosa oleh ekstrak kasar amilase yang meliputi konsentrasi substrat optimum dan waktu inkubasi optimum adalah 3\% (b/v) dan 75 menit. Semakin lama fermentasi kadar bioetanol semakin meningkat, yaitu untuk fermentasi hari ke-1 sampai ke-4 diperoleh kadar bioetanol sebesar 0,$8361 ; 2,2379 ; 5,7590 ;$ dan 10,5787\% (v/v).

\section{UCAPAN TERIMA KASIH}

Penulis mengucapkan terimakasih kepada Jurusan MIPA Fakultas Sains dan Teknik dan Laboratorium Biokimia atas izin yang diberikan sehingga penelitian telah dapat diselesaikan serta kepada Achmad Rosyadi atas kerjasamanya selama penelitian.

\section{DAFTAR PUSTAKA}

Anindyawati, T. 2009. Prospek enzim dan limbah lignoselulosa untuk produksi bioetanol. $B S \mathbf{4 4 ( 1 ) : ~}$ 49-56.

Agu, R.C., Amadife, A.E \& Ude, C.M. 1997. Combine heat treatment and acid hydrolysys of cassava grate waste (CGW) Biomass of Ethanol Production. Waste Management 17(1): 91-96.

Alexander, R \& Joan, M.G. 1993. Basic Biochemical Methods $2^{\text {nd }} e d$. New York: A John Willey and Sons.

Judoamidjojo, M., Darwis, A.A \& Sa'id, E.G. 1992. Teknologi Fermentasi. Jakarta: Penerbit CV. Rajawali.

Lingga. 1986. Bertanam Ubi-Ubian. Yogyakarta: Penerbit Swadaya.

Martoharsono, S. 1977. Dasar-Dasar Biokimia. Yogyakarta: Gadjah Mada University Press.

Merina, F \& Trihadiningrum, Y. 2011. Produksi Bioetanol dari Eceng Gondok (Eichhornia crassipes) dengan Zymomonas mobilis dan Saccharomyces cerevisiae. Prosiding Seminar Nasional Manajemen Teknologi XIII. Surabaya 5 Februari 2011.

Prihandana, R., Noerwijari, K., Gamawati, P., Adinurani., Setyaningsih, D., Setiadi, S \& Handoko, R. 2007. Bioetanol Ubi kayu Bahan Bakar Masa Depan. Jakarta: Agromedia.

Poedjadi, A. 1994. Dasar-Dasar Biokimia. Jakarta : Universitas Indonesia.

Putri, L.S.E. \& Sukandar, D. 2008. Konversi pati ganyong (Canna edulis Ker.) menjadi bioetanol melalui hidrolisis asam dan fermentasi. Biodiversitas 9(2): 112-116.

Rahayu, S. 2004. Karakteristik Biokimiawi Enzim Termostabil Penghidrolisis Kitin. Makalah 
Pengantar Falsafah Sains. Sekolah Pasca Sarjana (S3), Bogor: Institut Pertanian Bogor.

Reed, G \& Nagodawithana, T.W. 1991. Yeast Technolog, $2^{\text {nd }}$. New York: Van Nostrand Reinhold.

Roslan, A.M., Yee, P.L., U.K.M., Aziz, S.A \& Hassan, M.A. 2011. Production of bioethanol from rice straw using cellulase by local aspergillus sp. Int J Agric 6(2): 188193.

Samsuri, M., Gozan, M., Mardias, R., Baiquni, M., Hermansyah, H., Wijanarko, A., Prasetya, B \& Nasikin, M. 2007. Pemanfaatan sellulosa bagas untuk produksi bioetanol melalui sakarifikasi dan fermentasi serentak dengan enzim xylanase. Makara Teknologi II(11): 17-24.

Schlegel, H.G. 1994. Mikrobiologi U Kimia dan Proses. Jurusan Teknik Kimia Fakultas Teknologi Industri, Surabaya: UPN.
Wulan, P.P.D.K., Dianursanti \& Amsal, T. 2009. Pemanfaatan Limbah Pisang untuk Pembuatan Etanol. Makalah Proses Kimia Ramah Lingkungan. Departemen Teknik Gas dan Petrokimia, Fakultas Teknik, Depok : Universitas Indonesia.

Yoshimura, T., Hatakawa, M., Takhashi, F \& Kawashima, T. 2012. Study of bio-ethanol production from cellulosic waste (rice straw). J. Technology and Education 19(1):19-22.

Yoswathana N., Phuriphipat, P., Treyawutthiwat, P \& Eshtiaghi, M. N. 2010. Bioethanol production from rice straw. Energy Research Journal 1(1): 26-31. 